This is an author produced version of a paper published in Social Identities : Journal for the Study of Race, Nation and Culture. This paper has been peer-reviewed but does not include the final publisher proof-corrections or journal pagination.

Citation for the published paper:

Marr, Stephen. (2019). 'A town new and modern in conception' : non-racial dreams and racial realities in the making of Gaborone, Botswana. Social Identities : Journal for the Study of Race, Nation and Culture, vol. 25, issue 1 , p. null

URL: https://doi.org/10.1080/13504630.2017.1418602

Publisher: Taylor \& Francis

This document has been downloaded from MUEP (https://muep.mah.se) / DIVA (https://mau.diva-portal.org). 


\title{
'A town new and modern in conception': non-racial dreams and racial realities in the making of Gaborone, Botswana
}

\author{
Stephen Marr \\ Department of Global Political Studies, Malmö University, Nordenskiöldsgatan 1, 20506 \\ Malmö, Sweden \\ Phone Number: +46 40-66 58226 \\ Email: stephen.marr@mah.se
}

Funding Acknowledgement: This work was supported in part by a Fulbright Dissertation Research Grant.

Disclosure Statement: The author has no conflict of interest or financial stake in the research presented.

Acknowledgements: The author would like to thank both the editors for the opportunity to participate in this special issue of Social Identities and the anonymous reviewers for the helpful comments and suggestions in improving the essay. 


\begin{abstract}
Botswana has long been praised for its financial and political achievements. High economic growth rates and uninterrupted democratic governance since independence in 1966 have led to Botswana's labeling as the “African Miracle”. Long before Botswana’s emergence as a darling of Western development agencies however, Tswana elites and colonial officials also saw Botswana as exceptional: surrounded by states divided along racial lines, these individuals sought to construct a nation organized around principles of racial and tribal unity.

Aspirations of non-racialism were to be exemplified in Botswana’s newly constructed capital city, Gaborone. At the same time, underlying the planning vision for Gaborone was a competing set of narratives, practices and aspirations that undercut these lofty ideals and resulted in the creation of a city highly stratified by racial segregation. This essay identifies three complementary urban planning rationales that produced urban exclusion in Gaborone: the desire to build Gaborone as an administrative capital, borrowing from both colonial and indigenous Tswana traditions that privileged spatial divisions related to status and race, and the goal to build a "modern" urban center to lead Botswana into the future. These tensions divided the city in ways both familiar and unexpected and set the parameters determining who counts as a legitimate resident of the city. The paper therefore seeks to explore how a city founded on an ideal of racial unity instead became a site of stark division(s).
\end{abstract}

Keywords: Gaborone, Botswana, Africa, urban planning, colonialism, racial segregation

In the following essay, I examine how Gaborone, the capital city of Botswana built specifically for independence under the auspices of principles of non-racialism and equality, morphed into an urban environment characterized by a high degree of socio-economic stratification and segregation. To develop this narrative, I situate the essay in the late colonial and early independence years of the 1960s. My emphasis on Gaborone during this period adds to the expansive literature on colonial urban planning, architecture, and racial dynamics via two central arguments. First, the article suggests that indigenous Tswana spatial practices and cosmologies played a key role in the initial planning and subsequent administration of the city. Second, despite the egalitarian promise of Gaborone's founding narratives of nonracialism, modernity, and urban development, in practice, these aspirations excluded the vast majority of urban residents. Though specific to Gaborone, the discussion presents implications for the study other (post-)colonial cities, along with the murky dynamics between colonizer and colonized.

The story of Gaborone is not one populated by domineering figures or architectural giants. There was neither time, nor money, for sweeping gestures. Perhaps befitting its humble beginnings, Gaborone has not been the subject of sustained academic scrutiny, unlike other large-scale (post-colonial) urban interventions such as Brasilia (Holston, 1989), Abuja (Elleh, 2001), or Canberra (Vale, 2014). Yet the lesser-known, lesser-told history of Gaborone is no less dramatic, no less interesting and no less reflective of a time, ideology and way of thinking that continues to affect the political, social and economic lives of residents into the present. Early in his concise review of apartheid urban development in South Africa, Paul Maylam asks whether the South African case fits into the conventional narrative of colonial urbanism or is best considered as exceptional (1995, p. 22). The case of Gaborone reveals a similar dilemma.

The experience of Gaborone rings familiar in important ways. Carl Nightingale's massive history of urban segregation opens with the argument that three pillars contributed to the spread of divided cities across the world: governments, wide-ranging intellectual networks, and the growth of the real estate industry under global capitalism (2012, p. 5). As highlighted below, justifications for the development of Gaborone reflected then widespread discourses of utopia and modernism. In line with Rabinow's (1992, p. 54) notion of 'middling modernism' developed out of his work on French colonial experiments in Morocco, planners envisioned Gaborone as a transformative site from which new, modern citizens might one day emerge. 
While these aspirations were no doubt important to colonial-era planners, they were also significant to indigenous Batswana elites (see also: Njoh, 2009, p. 304) who were thus able to confirm their status at the forefront of Gaborone's burgeoning urban modernity.

Furthermore, in Gaborone, socio-economic segregation was considered inevitable, if not desirable, while the racial implications of these divisions were minimized. Gaborone thus echoes the experience of other colonial cities in Africa as well as sites as far afield as Chicago, in which segregation occurred via the 'camouflage' of non-racialism (Nightingale, pp. 318-319). A focus on economics considerations or property values softened the racial edges of urban segregation. Of course, as Njoh (2008, p. 588) notes, planners well knew the practical effects of these practices. Through ostensibly neutral technocratic regulations or moral claims about civilized values, city planners could “do" race without explicitly talking about race. Moreover, the fact that wealthy indigenous populations were able to buy their way into high-cost neighborhoods made non-racial camouflage even more effective. Elites in Gaborone, as in India or elsewhere in sub-Saharan Africa (Nightingale, p. 162), had little interest in living in close proximity to the urban poor or other "backwards" populations. Inspiration for Gaborone's planning thus reflects an amalgam of both French and British planning styles: the British tendency to emphasize housing density, class, and zoning, combined with the French focus on civilization and modernity.

At the same time, Gaborone extends understandings of colonial urban development. In part, this is due to the significance of indigenous spatial cosmologies and traditions. Nightingale, for example, makes the broad point that global practices and ideologies of segregation had to be open to local contexts in order to be successful (p. 13). That is, in the interface between the local and the global, institutions had to fit or take account of the 'cities' smaller stages, adapting plotlines of political dramas they developed in one place to the conditions they found in others (p. 13).' Similarly, Rabinow's work points to the way French architects repurposed traditional elements of Moroccan housing or urban design to fit their own civilizational or cultural aspirations (p. 55). The Gaborone case however, complicates this story in which particular practices are assimilated into universal standards - or, in Nightingale's phrasing, made available for 'play.'

Building on Goldberg's account of 'relational racism' (2009) and racialization (2006), I suggest below that understandings of urban spatial hierarchy, class and race were not simply brought to Botswana by colonial planners, but very much aligned with elite indigenous Batswana expectations of space, power, chiefly authority and segregation. Planners did not simply take disparate elements of traditional practice to make the capital familiar to Batswana elites and non-elites alike, but rather, indigenous urban practices and assumptions mattered: they helped legitimate the capital project. Instead of a stark boundary between the local and the global, or the traditional and the modern, in Gaborone we see an interactive complementarity between indigenous and modernist aims.

The preceding observation adds another layer to our understanding of 'ambiguous' African cities (Wright, 2001) and offers a new line of connection within the analytical field the colony and the metropole both inhabit (Goldberg, 2009, p. 1275). Maylam has argued that the continuities in South Africa's urban development are more consequential than the discontinuities (p. 34). Gaborone's urban history suggests something similar. But, at the same time, points to the fact that it is necessary to extend the search for continuity so as to include the role(s) played by indigenous spatial practices and hierarchies.

Before engaging Gaborone's particulars more fully, I offer a few points to contextualize the upcoming discussion. The building of Gaborone occurred over the course of a few frantic years in the mid-1960s. Though initial estimates pegged the cost to complete the capital project at $£ 11$ million (Headquarters Development Committee, 1962, December 14), only $¥ 7$ million in funding was actually available (New York Times, 1965). The severe financial 
constraints meant that the early planning of the city was conducted by a largely anonymous group of colonial officials and architects, aided occasionally by tropical planning and housing officials from London, who derived their inspiration from town planning techniques borrowed from Western cities, other British colonies, and the surrounding region.

The transition from dusty backwater to what is now a cosmopolitan regional economic hub would make the city virtually unrecognizable to the individuals who built it five decades ago. At the time of construction, the population of what was then called Gaberones consisted of a few permanent residents surrounded by a small government outpost including a jail and a public works camp. In 1971, five years after independence, the number of residents in Gaborone remained low, constituting approximately 3\% of the country's population (17,700 individuals) (Central Statistics Office, 2001). Because of the country’s low population, pervasive poverty, lack of infrastructure, and bleak economic prospects most observers expected that Gaborone would look much the same well into the future (Legislative Council, 1961, pp.45-46). ${ }^{1}$

In the face of these obstacles, Botswana's first president, Seretse Khama exhibited optimism about the future. Khama asserted in a 1972 speech to the ruling Botswana Democratic Party annual congress that despite the country's peripheral political and economic status, '....Botswana is widely regarded as a beacon of hope in a troubled region, a force for constructive change (Khama, Carter and Morgan, 1980, p. 144).' In a region surrounded by apartheid states, Botswana's influence turned on its ability to serve as a model of non-racial citizenship. Gaborone was to function as a primary driver of this hoped for regional transformation. The tensions between these lofty aspirations and the planning models and visions used in the development of Gaborone, however undercut the goal of a non-racialized urban environment: segregating the city by economic class effectively meant that the city was segregated by race. These initial planning decisions and objectives continue to weigh on the contemporary situation in Gaborone.

The remainder of the article unfolds as follows: I first address the initial hopes for Gaborone as a restricted administrative center. The subsequent section outlines the indigenous and regionally-based planning models that inspired and legitimated the development of Gaborone. The final substantive segment considers the idea that the new capital, as a modern city, would help produce similarly modern citizens fit to lead Botswana into the future. A brief conclusion connects the findings to some contemporary issues related to the study of race, urban space, and exclusion.

\section{Gaborone: administrative capital for an independent Botswana}

Characterized by the then Chief Secretary A.J.A. Douglas as a friendly 'invasion' into 'our own country,' the initial transfer of personnel and equipment from Mafikeng to Gaborone occurred early in 1965 (Kutlwano, 1965, p. 2). Placing the capital - then located within South Africa - within the boundaries of the Bechuanaland Protectorate was the first in a series of important events culminating in the establishment of Batswana self-governance following Independence in September 1966. To the individuals in charge of selecting a site for the new capital, Gaborone offered an opportunity to custom build a city. On the one hand, planners felt that already existing towns lacked the requisite visual pomp and 'dignity' expected of a properly laid out capital city (Legislative Council, 1961, pp. 45-46). At the same time, the emptiness of the location was expected to encourage harmonious race relations. Both influential Africans and Europeans emphasized that the racial and tribal unity of both the country and new capital was of paramount importance as the territory moved towards independence (1961, pp. 26; 28). 
In the debate to decide on the new headquarters' location, Seretse Khama, in the first substantial speech supporting the recommendation of Gaborone, argued that the success of Botswana's non-racial experiment depended on the selection of a 'neutral territory' where 'we can put into operation the policy which we all wish to see associated with this country' because of the absence of 'set ideas' amongst the residents of the town (Legislative Council, 1961, pp. 9-10). It was assumed therefore, that the government would have a far easier time cultivating a non-racial culture in a spot where racist attitudes had not had time to take root.

Of course, though, the achievement of non-racialism was easier said than done. According to a former colonial official stationed in Gaborone during the capital project's early development, problems related to discrimination were prevalent. He writes:

\footnotetext{
'This racial state of affairs seemed to me to pervade the whole Gaborones [sp] camp. The PWD [Public Works Department Camp] was a hotbed of racial attitudes as many of the mechanics, fitters etc. hailed from South Africa or Rhodesia where such attitudes prevailed amongst artisan types. Not that many of the people who hailed from the UK were much different (George Winstanley, 2006, personal communication).'
}

Winstanley goes on to note however, that during construction, and in the years immediately following the city's completion, the old colonial establishment was replaced by a younger set of officers who while 'not woolly liberals' did 'think differently.' These new attitudes were exhibited in the formation of discussion groups and a new social club in Gaborone whose membership was open to both elite whites and blacks. I would suggest however, that discrimination was more easily overcome amongst people of relatively equal social and political positions. The racial harmony strived for in the planning of Gaborone seemed contingent on a person's class position. Racial harmony for either Tswana elites or the whites didn't mean consorting with African laborers or the urban poor.

The restricted scope of 'racial harmony' is demonstrated in pre-independence Legislative Council debates in which members argued that Gaborone should function solely as an administrative center, home only to government functionaries, their families and attendants. ${ }^{2}$ These preferences help account for the underestimation of the future population of the city and the near complete lack of preparedness to deal with the influx of poor rural dwellers that came to Gaborone in search of better prospects. A member of the Legislative Council at the time, a Mr. Sim (Legislative Council, 1961, p. 17) argues,

'The inhabitants of this territory desire that the new capital will be a town of beauty, with parks and gardens, with avenues lined with exotic trees, with wide streets, with traffic islands with either lawns or flowers in the centre, and an imposing Legislative Council Chamber.'

He concludes by stating that the site for Gaborone allows for the possibility of 'making this new capital a modern garden town (1961, p. 19).' I quote at length from Dr. Merriweather's (1961, pp. 25-26) similar dream for Gaborone:

'I do not think that the administrative capital should be mixed up with the noise, bustle and squalor of an industrial area. When we think of an administrative capital, we think of peace and quietness, we think of the gentle rustle of papers, and gentle clink of cups of tea, we think of the tip-toeing of messengers taking portfolios from one office, one department to another in an everlasting circle and this would hardly fit in with a busy industrial area! Think of Scotland! There, over on the west, we have a great dense population of the Clyde-side, we have the great industries and the noise and the turmoil and the slums, and the smoke. We come over to the capital in the east, Edinburgh, where we find the dignity and the quiet of a capital city and I think we can take a lesson from that. Let us have out administrative capital where it can be developed into a beautiful and dignified place and I think Gaberones is most suited for that.' 
As envisioned by white colonial officers, Gaborone embodies a colonial fantasy in which industry, noise, and the African urban poor are absent. Some Batswana officials harbored a comparable vision. Kgosi Batheon (1961, p. 50) says of his ideal capital: 'We would not like to be pestered with [the] noise of railway engines, with smoke and all industrial activities when we want to have our minds collected, when we need to be at peace discussing [the] major problems of the Territory.'

The various drafts of the town plan for Gaborone came to reflect these concerns for an administrative Eden characterized by quiet, cleanliness, and a town free of riff-raff. The achievement of harmonious race relations in the 'pristine' location was ultimately a task made easier when those who might present problems were left out of the idealized elite vision of the city. In the next section, I extend the argument by examining the role that both colonial and pre-colonial spatial cosmologies seeped into the plan for a non-racial Gaborone, further normalizing urban exclusions.

\section{(Pre-)colonial legacies and the making of Botswana's city of tomorrow}

Connecting colonial and Tswana approaches to spatial arrangement makes the planning history and development of Gaborone more comprehensible because of overlapping understandings and practices of hierarchy and spatial organization. Because Tswana elites had substantial influence in the decision-making process in the years preceding independence, it must be asked why they assented to a city starkly divided along class and racial lines despite the stated objectives to the contrary. Existing Tswana conceptions of chiefly authority, a stratified socio-economic hierarchy, and established patterns of spatial organization made the final plan of Gaborone both acceptable and intelligible to the Tswana authorities who had an influence on both its conception and implementation. These indigenous elite expectations complemented attitudes about race, economics, urban citizenship and planning held by the colonial bureaucratic machinery providing the financial and logistical backing for the capital project.

Although a full accounting of pre-colonial chiefly authority is well beyond the scope of this essay, a few points warrant mention. First, Seretse Khama linked the chiefly past and democratic future. Gulbrandsen (1995, p. 437) has elsewhere pointed out that because Khama represented the 'new men' - educated, non-tribal leaders who would come to dominate the independence government - along with his position as the rightful royal heir of the largest Tswana tribe, he was uniquely positioned to easily 'bridge [the] patrimonial and republican systems' of government. From the onset of independence, the ruling BDP has demonstrated significant 'ideological continuity' with practices and ideologies previously identified with elite-dominated chiefly politics (1995, p. 437).

In pre-colonial and colonial Botswana, the position of the chief in the political, productive, cultural and religious realms was paramount. The chief of a Tswana tribe was, among other duties, simultaneously judge, philanthropic benefactor, general, diplomat, and lawmaker of the tribe (Schapera, 1953, p. 51). Although the chiefs' powers and duties were transformed following the establishment of colonial rule under the British, the Tswana dikgosi retained much of their symbolic authority and traditional responsibilities up until the conclusion of colonial rule (Silitshena, 1979, p. 55). As many scholars of Botswana state formation and politics have noted, rather than supplanting the chiefs, the already established norms of obedience and the emphasis on social harmony were well suited to British colonial policies. The chiefs and colonial officials thus became easy and willing collaborators (Good, 1999, p. 188; Silitshena, 1979, p. 60). Others (Gulbrandsen, 1995, p. 436; Truschel, 1974, p. 73) go further and suggest that the imposition of colonial rule actually increased the power of the 
Tswana chiefs, as they became less beholden to the opinions and feelings of their subjects. Instead their legitimacy now flowed from the approval and support of the colonial authorities. Even into the post-colonial present, the presidents of Botswana have adopted some of the symbolic rhetoric of the politics of the past, thereby linking them both to the moral order and to the largely unopposed authority previously represented by the chiefs. The president of Botswana, for example, carries the informal title of Tau e tona ('the Great Lion'), which functions as a not so subtle nod to an important symbol of traditional power: the skin of the lion that adorned a newly crowned chief (Tlou, 1974, p. 68).

A related point is the way which chiefly authority structured understandings of citizenship, which derived from an individual's social and economic position in the tribe. Broadly, Tswana society was segmented into three divisions: a) Nobles; b) Commoners; c) Immigrants (Schapera, 1953, p. 36). This socio-economic and political segmentation is of particular interest here because authority and hierarchy were inscribed into the space of the village. The built environment constituted an expression of status and position in the community. The chief played an oversize role in establishing these spatial patterns. For example, prior to colonialism and efforts to fix the locations of Tswana settlements, villages moved frequently in pursuit of water or resources (Morton, 2004, p. 364). Strict rules governed the construction of newly established villages: new villages would have essentially the same layout and design as the one just abandoned (Wareus, n.d., p. 5). MacKenzie (as cited in Reid et. al., 1997, p. 375), an early missionary into the region, described the procedures dictating the layout of the village:

'... in the case of the Bechuana town[,] as soon as the chief's position is ascertained, one says, "My place is always next [to] the chief on this side;" another adds, "And mine is always on that side," and so on till the whole town is laid out. The chief is umpire in all such matters, and settles all disputes about ground, etc.'

The central role played by the kgosi in arbitrating the organization of the village is also evidenced by the core location his primary residence held in the village. Everything in the village existed spatially in relation to his home (and the royal kraal and kgotla). The schematic of the village as laid out by Tlou $(1974$, p. 73$)$ shows the chief's dwelling at the center of a series of concentric circles radiating out from the center; closest to the chief would be his advisors and other royals, while located further away sat the homes of the commoners, immigrant and serf populations. This 'structured ward settlement centered upon the kgosi's ward meant a consolidation of power through a hierarchical set of spatial relationships (Morton, 2004, p. 347).' The centralized settlements of the Tswana revolving around the chief, and administered by his delegates on the periphery, thus enabled the chief to keep close watch and supervision over the movements of people and the activities ongoing in his territory (Schapera, 1935). Power was thus 'built into the very materiality of place (2004, p. 349).'

If placement at the center represented power and authority, the residence of serfs and immigrants at the margins conversely indicated a corresponding powerlessness. Typical of Tswana settlement patterns is the placement of the immigrant, ${ }^{3}$ marginalized, conquered or laboring classes at the edge of the village (Schapera, 1953, p. 35). Chiefs preferred to have these populations kept at arms-length (Kuper, 1982, p. 259). Kept apart, in other words, from the sites, symbols and locations denoting political and economic power. The maintenance of these stark distinctions determining who lives where, served to reify one's position in Tswana society.

Stratified settlements in which the boundaries between subjects and elites defined by their association to a royal ancestry or large-scale cattle herding were distinctly laid out, were common across the majority Tswana tribes. Founding a new capital along these lines would 
have seemed an acceptable, if not inevitable, outcome for elite Tswana leadership during the Independence period. The legacies of these practices intersected with colonial ideas about planning imported to Gaborone that helped legitimate the particular conceptions of modernity, citizenship, city life and belonging inscribed into the space of the city.

From the get-go, planners were at pains to clarify that class and not racial ideology was to be the basis of segregation. The authors of an early planning report, for example, note, 'every attempt has been made to provide a town plan which postulates no particular social or political or economic ideology, but is based at all times upon hard economic and sociological facts (Bechuanaland Protectorate, n.d., p. 3).' In pursuit of this objective, Otto

Koenigsberger, a widely recognized expert on building in 'tropical' colonial environments in the employ of the home offices in London, suggested to the Protectorate officials that each neighborhood within the town be conceived of as a whole, therefore resulting in a close intermingling of low, medium and high cost housing (Headquarters Development Committee, Minutes of the Meeting, 1962, June 13). This recommendation was received as a 'fundamental' difference to the plan created internally by the Protectorate officials and was viewed rather derisively. 'Our [plan],' the Chairman of the Headquarters Development Committee explains (1962, June 13), 'was based on the idea that the town as a whole would be a unit which would consist of different neighbourhoods, each with its own distinguishing density and catering for a particular class, irrespective of race.' Another member present at the same briefing 'deplored' Koenigsberger's suggestion because 'people of different income levels and different interests would not wish to live in a tight residential community (1962, June 13).' The distinction between 'town as whole' and 'neighborhood as whole' articulated in the debate over the plan, highlights the apprehensions about living too close the poor/African population. Officials on the one hand could advocate for a town divided by class, rather than race, while at the same time, feel quite comfortable in the knowledge that a town segregated by class would also be divided by race, save for the acceptable, Westernized Batswana 'new men' who made up the minority elite. The plan for Gaborone that emphasized residential compartmentalization as a means conducive to urban development to come came with the added consequence of sustaining and perpetuating racial segregation (Czegledy, 2003, p. 24).

Into Botswana seeped planning ideas and approaches from places like Rhodesia and South Africa. These influences are found in planning style and ideology, as well as in the more technical and practical aspects of high-density neighborhood development. The rigorous application of organized, modernist, and ostensibly scientific planning techniques that privileged 'efficiency' over 'disorder' was first attempted in South Africa (Bozzolli, 2000, p. 92). Modernist planning propelled by its emphasis on practices devoted to the establishment of green belts, rigid zoning, and the social health of communities, was therefore eventually directed to creating, and later, maintaining the segregationist spatial framework of the South African regime (Mabin and Smit, 1997, p. 204). Planning was not simply a technical concern, but became fundamentally bound to a more ambiguous moral terrain in which the way life should be lived, politics practiced, or power distributed was contested.

Spatial theories whose principle concerns revolved around issues of order, organization and stability prompted an easy transition to more specific regulations grappling with where and how poor Africans lived. State and local governments, along with private industry, had an interest in managing the lives of their citizens and employees. For businesses, the problem of African housing was a balancing act requiring working populations be located close enough to urban areas in order to participate in the engines of production, but far enough away from the respectable parts of the city so as not to contaminate it or encourage intermingling (Demissie, 2004, p. 500). And for the state, the control and management of African housing was deemed necessary in order to prevent the formation of opposition 
movements that might pose it a threat (Parnell and Hart, 1999, p. 375). As White (1990, pp. 131-132) points out in her study of housing and prostitution in colonial Nairobi, the presence of autonomous individuals tied neither to the formal economy nor to the state represented an intolerable danger to the government. The construction of housing for Africans, first in the form of barracks or hostels, and later, in small houses to be occupied by a worker and his immediate family, provided the authorities with a means to monitor a potentially dangerous population. The hostel-barracks erected in South Africa represented what Bozzolli (2000, p. 98) termed a 'mad form of modernity' relied exclusively on prison-like methods to keep control of its occupants. Meanwhile, the African neighborhood composed of single-family houses offered a more subtle vision of control. Advocates of large-scale construction projects composed of austere tract housing argued that the inculcation of western ideas of moral values and family life would train the African working classes to become proper law-abiding, nonthreatening individuals who would become a 'society of compliant citizens (Home, 2000, p. 330).'

Planners in Gaborone, when considering where and how to house the African working population-space for non-working Batswana was not included in the plans for the citydidn't attempt to reinvent the housing wheel. Instead, they made use of the examples presented by their closest neighbors. Planning officials made use of tried and true formulas about low-cost housing, merely tinkering with questions of practicality and logistics in order to fit these schemes into the specific financial and political circumstances of the Protectorate. It doesn't appear that those involved in the planning paid much attention to the contradiction between their mandate to create a new kind of city in sub-Saharan Africa and their decision to replicate, in Gaborone, the very urban models used in support of the kinds of regimes from which Bechuanaland was trying to distance itself. The document record suggests that although the planners of Gaborone saw housing as a technical problem in need of a solution, the fact remains that they adapted urban spatial practices expressly developed in order to preserve a particular set of unbalanced power dynamics.

More than other facets of the plan for the new capital, the issue of low-cost housing brought to the fore the tensions and contradictions present in the oft-stated desire to create a new kind of urban environment. The lofty aspirations Batswana and colonial elites often spoke of rarely corresponded to the planning schematics produced by the Protectorate's government. Class, race and social fissures were most visible, and perhaps most intractable, with regards to low-cost housing in Gaborone. Decisions taken tended towards the safe and conservative rather than something that might radically transform the political, social and economic landscape.

Early on, there was recognition by the Assistant Attorney General and others that the success or failure of the new city would be judged according to the type and quality of accommodations provided for the 'lower grade employee (Headquarters Development Committee, Report of a Meeting, 1962, April 10).' Accordingly, the suggestion of the British government consultant, Kenneth Watts (1963), sent to the Territory to advise on the Capital Project, urged local officials to move beyond the 'individual box' mentality for low-cost African housing popular in Southern Africa. Yet, the open-ended possibilities presented by a city that existed only in minds or on paper in the early 1960s were characterized in terms of prevention. The Assistant Secretary of Townships, Works and Communications framed the task in Gaborone to be not one of 'organiz[ing] and improve[ing]' an existing city, but how to 'prevent unsatisfactory development' in a place not yet built (Windsor, 1963). How, in blunter terms, could a city be established that would lack slums both in the present and into the foreseeable future? As the District Commissioner for Gaberones, P. Cardross-Grant, is recorded arguing in the minutes of an April 1963 meeting of the Headquarters (Development) Sub-Committee, the prevention of 'slum conditions in Gaberones' must be the guiding 
principle of all planning decisions taken by the Protectorate Government (1963). Debate over the quality of housing evidenced by those involved in the planning of Gaborone likely stemmed not from a concern over the well-being of the people who would be occupying these houses, but rather, from a worry that unsightly slums might have a derogatory influence on the viability of the new capital's self-image as a new kind of city in Africa or impinge on the expected quality of life the new capital was to afford the elites.

Two of the most problematic contradictions surfaced due to the continued insistence on maintaining a city divided by class but not race. First, the goal of a city founded on non-racial principles was at odds with the government's borrowing of housing models utilized in racist regimes and colonial settings. In 1956, long before the decision to relocate the new capital from Mafikeng was taken, 'African Housing,' as it was typically labeled in the files and memos of the period, in places like Gaberones and elsewhere was already considered an urgent policy matter. One suggested solution to the problem was to house the urban African population in 'locations' of the sort that might be found in the South Africa or Rhodesia. 'The provision of African housing,' the minutes of one meeting read,

\footnotetext{
'other than for a small number of domestic servants, is a normal local government responsibility, and usually takes place in what is called a "location," a centre of African settlement in a township area, where such settlement, its sanitation and control can be effectively managed. It is obviously more desirable that Africans be decently housed amongst their own fellows than they be huddled together in overcrowded hovels in the insanitary (sic) back-premises of stores and industrial concerns. There are employees too who do not desire the residence of domestic servants in close proximity to themselves (Bechuanaland Protectorate, 1956).'
}

The creation of a separate urban space for the (African) working population was discussed as being solvable through the construction of hostels or single-family housing units. Although the Europeans considered hostels an easy solution to their desire to keep the new capital 'neat and tidy (Headquarters Development Sub-Committee, 1963),' this option was ultimately rejected due to their failure in Southern Rhodesia and the disdain felt towards these residences by the people expected to live in them (Secretary for Townships, Works, and Communications, 1963). If hostels, of the sort tried on the Copperbelt to the north, for example, were not the answer, planning officials looked to the South: to the mines of Kimberly and the suburbs of Johannesburg.

Into the 1960s, advice about how to house most efficiently the Tswana urban population was sought from South Africa, including a June 1962 trip by the Secretary of Townships, Works and Communications (A.N.W. Matthews) and the Director of Public Works (W.O. Davies). Following their return, the housing estates are described as 'most depressing; rows upon rows of houses gave no atmosphere to the estates. In Kimberly, the estates were soulless - trees had been ripped out, stand pipes were provided only once every $400 \mathrm{ft}$. (Headquarters Development Sub-Committee, 1962).' A blunter judgment appears in their firsthand account of the trip:

\footnotetext{
'A regrettable feature noted during the visit to the Government Housing Scheme [in Johannesburg], was the unsightly tin hut additions [emphasis in original] to the standard brick buildings. These 'shack-like constructions must have been sanctioned by the estate managers, but the effect was depressing, and the ultimate result must be the propagation of the evil [emphasis in original] that the Estates were intended to replace-Shanty Towns (Bechuanaland Protectorate, 1962).’
}

Although the negative assessment provided above seems to preclude the possibility of 'townships' of the type populating South Africa's urban landscape, there remained some ambivalence about the utility of this style of residential organization for the Protectorate. On 
the one hand, officials were leery of bringing a location 'system' across the border, as they did not want to be bothered with its attendant 'administrative and political difficulties (Bechuanaland Protectorate, 1961).' Yet, in a memo written approximately three weeks later, the provision of a 'satellite township' was thought to be the optimal way to proceed. The document predicts that because the 'majority of occupants for many years to come will be semi-tribalised, and will [therefore] not wish to mix either with the more highly educated and paid African or European (Public Works Department, 1962a).' Due to the tension between the wish not to outright mimic the discriminatory practices conducted in South Africa and the unappealing - for the White and Tswana elites - option of living in close proximity to 'semitribalised' Batswana, the construction of low-cost housing in Gaborone ultimately adopted some of the principles and techniques found elsewhere in the region.

Part of the problem facing the government as it settled on a housing policy was a somewhat muddled conception of who would eventually inhabit the city. In the plan's formative stages, colonial officials dismissed the possibility that the capital would attract many Batswana. They tended to characterize much of the labor presence arriving in the city as 'temporary (Hansard, 1963)' or 'migratory (Department of Public Works, 1962b, p. 14).' As a result, there was no real plan for what to do with the poorest and unemployed migrants who might make their home in the city despite the absence of employment opportunities. As outlined below, Gaborone was envisioned to be a modern city inhabited by a modern population. Migrants circulating between the urban and the rural would disrupt the new kind of life practiced in the capital because they would not conform to the behaviors and values the ruling Tswana and colonial elites envisioned to be present in a modern urban citizen. Indeed, a memo written by D.A.T. Atkins, a onetime District Commissioner of Gaberones, suggests that the Batswana permanently inhabiting the new urban space of the capital would not be typical of those who remained behind in rural areas. Africans in Gaborone will inevitably not 'fall into the normal definition of peasants in this Territory (Atkins, 1960).' Taking up residence in Gaborone did not merely signify a change in address, but represented part of a process of urbanization that culminated in a complete transformation of an individual's life. Temporary African residents were designated unfit for Gaborone living due to the danger of contamination presented by their rural or non-modern ways.

\section{“A town new and modern in conception": Gaborone as engine of transformation}

Refrains exhorting the citizens of the territory to develop socially, economically and politically were common in the independence period. Capturing the mood of the time, the Protectorate's publication Kutlwano (1965) proclaimed in a headline on the first page of the first issue following the election that installed the BDP into power: 'The Word to Remember is - Progress.' Following Ferguson's argument (1999, p. 5) that 'an urbanizing Africa was a modernizing Africa', Gaborone remained central to this mandate for Progress. In a 1970 speech entitled, 'A Developing Society,' then Vice President Quett Masire echoed these themes: 'We value our traditional way of life, but to survive and progress, we must adapt. We must adapt our customs to enable development to proceed without undue hindrance....In brief, ours is an extremely pragmatic and realistic approach (Khama, Masire, \& Dambe, p. 3).'

In a Legislative Council debate a few years earlier, Masire similarly argued that the necessary processes of modernization must be flexible and accommodating of that 'that element of society which is evolving from the lower type, from the semi-primitive type where people are mechanistic and are merely clay in the hands of tradition (Legislative Council, 1963, p. 27).' Written into official state policy following independence was the need to 
modernize. The National Development Plan, 1968-1973 (Republic of Botswana, 1968, p. 61) recognizes that the rate of development 'depends on the extent to which the majority of the population are prepared to change their traditional attitudes for a more modern and scientific mode of life.' Furthermore, 'in a country such as Botswana, where the life of most of the people is determined by tradition, all development means change-change not only in the way of life but also in the attitudes and values which underlie this way of life (1968, p. 61).' Botswana's leadership, from the earliest, participated in and reflected global discourses on themes such as modernity, social evolution and progress. Indeed, whatever reluctance there was regarding change during this period, more often than not, it had to do with the pace of change, rather than skepticism of the need for change.

These statements serve as evidence of a broader pattern of thinking prevalent at the time present in far-reaching discussions about urban planning and living conditions in the Protectorate. Masire identified a 'situation' in need of immediate attention regarding 'huts having been thrown all over the place in an unorderly manner (Legislative Council, 1964, p. 79).' This shabby state of affairs in the villages contradicts a fact that Masire says all Batswana must now recognize: 'times have changed and we with them, not only that, modern life, modern standards of living have placed greater demands on us to improve ourselves... (1964, p. 79).' Seretse Khama too, invoking language that echoed Le Corbusier's revolutionary call to choose linear geometry and order rather than the unplanned streets and chaos of the donkey cart, argued that for Batswana to

'go on in the same old way for fear that somebody else would like or prefer a winding road to a straight one, or would rather go on in the same old-fashioned way, when we know that properly surveyed and laid out villages are more attractive than the present type of villages that we have, is entirely erroneous (1964, p. 81).'

Planners reflected these aspirations, declaring their intention to design a city both 'new and modern in conception (Department of Public Works, 1962b, p. 5).' Both bureaucrats and civil servants saw their charge as directing the comprehensive transformation of entire ways of living, doing and thinking. They recognized the benefits of the Territory's African population living according to customary patterns. A people ostensibly unspoiled by civilization would no doubt prove easier to mold: 'the advantage is on our side in so far as we can endeavour to guide the African into an urban way of life should the necessity arise... (1962b, p. 2).' This transition, it was assumed, would be long and difficult, as the Department of Public Works elsewhere notes (1962c, p. 13), the citizens of the 'Protectorate live under tribal conditions [,] have done so for centuries, and it is considered likely that they will do so for many years to come.' Even after independence this characterization of Batswana persisted, as one scholarly observer (Best, 1970, p. 11) noted, 'the Batswana are not a politically conscious people,' whose lack of 'aware[ness] of national objectives and international affairs' can be partially countered by the country's exemplar of progress, Gaborone. The accepted, if unstated, wisdom exhibited in planning manuals and elsewhere in the document record is the belief that while a capital city would be built, most of the Africans in an independent Botswana wouldn't be prepared to live —or, at least, live properly — within its borders. The image of Gaborone offered here is one of a city ahead of its time and without citizens, a nostalgic monument built with a view to a modern future.

Blueprints outlining the imaginative and physical spaces of Gaborone enabled the State to separate the wild from the tamed, the civilized from the backwards, while granting the hope of directing the African population's transition to a lifestyle more in line with Westernized practices and expectations. Indeed, in those descriptions of the plan suggesting that the least developed Batswana reside on the fringes of the city, moving closer to a privileged center only after they’ve become suitably urbanized, one can envision Gaborone as a geographic 
representation of the population's Westernization. Viewed from above, at the abstract level of the plan, someone's level of development could be determined merely by locating their address on a map. Achieving this level of knowledge required the carefully regularized placement of people. Conversely, temporary workers and the temporary places they occupied, which were neither permanent nor easily counted, were anathema to the creation of the town 'new and modern in conception' Gaborone was to exemplify.

\section{Conclusion}

In the preceding essay, I argue on behalf of the importance of indigenous notions of power, hierarchy, and spatial cosmologies in Gaborone's founding. Traditional practices offered, to both elites and non-elites, a patina of legitimacy and familiarity to the layout of the capital. The findings presented here suggest that a complete understanding of African urban development in the colonial period and after requires the inclusion of pre-colonial histories and practices. At the same time, I argue that the utopian quest to manifest in Gaborone a new kind of urbanity in (Southern) Africa, premised on forward-looking notions of non-racialism and progress, excluded the bulk of the city's residents. These choices reverberate into the present. Legacies of racial and socio-economic segregation wield a long reach, leaving 'indelible marks on the built environment (Njoh, 2009, p. 303).' And indeed, a persistent source of conflict in Gaborone is about who can lay legitimate claim to a right to the city. Echoing present debates about the role and presence of race, claims to non-racialism in Gaborone largely 'rendered [race] invisible (Goldberg, 2006, p. 339),' yet its effects remain, unmentioned and 'unseen.' The preceding claim points to the need to reappraise analysis of the historical urban record in Gaborone.

Across sub-Saharan Africa, segregation continues to be a defining characteristic of urban development. Indeed, echoes of earlier exclusionary styles, intentions and justifications are present even in the continent's most modern and hi-tech urban developments (Marr, 2017). Separate urban settlements intended for a cultural and economic elite seeking security, reliable infrastructure, and consumer comforts, such as Lagos's Eko Atlantic City project or Kinshasa's Cité du Fleuve, are reminiscent of the hill stations of the colonial past. Like calls for non-racial city planning, ostensibly progressive and laudable urban policy goals mask more insidious and segregationist intent. To what extent these forward-looking "smart" and sustainable urban developments auger a future-tinged colonial present directs our attention to a set of political and social questions in urgent need of further investigation.

\section{Notes}

1. These expectations turned out to be wildly off base. By 1975 the population of Gaborone had already doubled to over 34,000 people (Stephens, MacLiver, and Weimer-Schultz, 1977, p. 92). Please note that further clarification and details are available in my dissertation manuscript, from which much of the empirical material is drawn (Marr, 2008).

2. An expert technical officer from London who briefly visited the Protectorate to consult on the planning project advised that the initial expected population of Gaborone would be 5,000 individuals. 2,000 of whom would be government officials and their dependents, while the remaining population would be composed of Africans who would provide services and support. See: Kenneth Watts, 'The Planning of Gaberones, the New Capital for Bechuanaland: Report of an Advisory Visit: January 1963’ (Collected Files, 'Gaberones Headquarters: Town Plan', Botswana National Archives, File Reference Number S. 592/8, Gaborone, 1962-1963).

3. Worth noting is that the position of the immigrant differs from that of the serf. A foreigner, particularly someone from a neighboring Tswana tribe, would eventually be assimilated into the tribe completely, thus losing their 'immigrant' status and adopting the full array of privileges afforded by citizenship. 


\section{References}

Best, A. C. G. (1970). Gaberone: Problems and prospects of a new capital. The Geographical Review, LX(1), 1-14.

Bozzolli, B. (2000). Why were the 1980s 'Millenarian?' Style, repertoire, space and authority in South Africa’s black cities. Journal of Historical Sociology, 13(1), 78-110.

Central Statistics Office, Republic of Botswana. 2001 Population and Housing Census [Table 1.6]. Retrieved from http://www.statsbots.org.bw/

Czegledy, A. P. (2003). Villas of the Highveld: A cultural perspective on Johannesburg and its northern suburbs. In R. Tomlinson, Beauregard, R., Bremner, L., \& Mangcu X. (Eds.), Emerging Johannesburg: Perspectives on the postapartheid city (21-42). New York, NY: Routledge.

Demissie, F. (2004). Controlling and 'civilising natives' through architecture and town planning South Africa. Social Identities, 10(4), 483-507.

Elleh, N. (2001). Abuja: The single most ambitious urban design project of the 20th century. Weimar: Verlag.

Ferguson, J. (1999). Expectations of modernity: Myths and meanings of urban life on the Zambian copperbelt. Berkeley, CA: University of California Press.

Goldberg, D. T. (2006). Racial Europeanization. Ethnic and Racial Studies, 29(2), 331-364.

Goldberg, D. T. (2009). Racial comparisons, relational racisms: Some thoughts on methods. Ethnic and Racial Studies, 32(7), 1271-1282.

Good, K. (1999). The state and extreme poverty in Botswana: the San and destitutes. The Journal of Modern African Studies, 37(2), 185-205.

Gulbrandsen, Ø. (1995). The king is king by the grace of the people: The exercise and control of power in subject-ruler relations. Comparative Studies in Society and History, 37(3), 415-444.

Holston, J. (1989). The modernist city: An anthropological critique of Brasília. Chicago, IL: University of Chicago Press.

Home, R. K. (2000). From barrack compounds to the single-family house: Planning worker housing in colonial Natal and Northern Rhodesia. Planning Perspectives, 15(4), 327-347.

Khama, S., Carter, G. M., \& Morgan, E. P. (1980). From the frontline: Speeches of Sir Seretse Khama. London: R. Collings.

Khama, S., Masire, Q. K. J., \& Dambe A. M. (n.d.). Development in Botswana: Speeches by Sir Seretse Khama, Dr. Q. K. J. Masire and Minister of Agriculture Mr. A. M. Dambe. Gaborone: The Government Printer.

Kuper, A. (1982). Social aspects of Kgalagari settlement. In R. R. Hitchcock and M. R. Smith (Eds.), Proceedings of the symposium on settlement in Botswana: The historical development of a human landscape (258-263). Gaborone: The Botswana Society.

Kutlwano. (1965, March). From Mafeking to Gaberones. 4(3), 2.

Kutlwano. (1965, March). The word to remember is 'progress'. 4(3), 1.

Mabin, A., \& Smit, D. (1997). Reconstructing South Africa's cities? The making of urban planning 1900-2000. Planning Perspectives, 12(2), 193-223.

Marr, S. (2008). Spaces of aspiration, liberation and exclusion: The politics of urban space in an African democracy (unpublished doctoral dissertation). University of Florida, Gainesville, FL.

Marr, S. (2016, November). Infrastructure, climate citizenship and exclusion in Lagos, Nigeria: A view from the Eko Atlantic City. Paper presented at the Annual Meeting of the African Studies Association, Washington DC.

Maylam, P. (1995). Explaining the apartheid city: 20 years of South African urban historiography. Journal of Southern African Studies, 21(1), 19-38.

Morton, C. (2004). Fixity and fluidity: chiefly authority and settlement movement in colonial 
Botswana. History and Anthropology, 15(4), 345-365.

New York Times. (1965, January 2). A new life begins in Bechuanaland: Protectorate transforming hamlet into capital. 80.

Nightingale, C. (2012). Segregation: A global history of divided cities. Chicago, IL: University of Chicago Press.

Njoh, A. (2008). Colonial philosophies, urban space, and racial segregation in British and French colonial Africa. Journal of Black Studies, 38(4), 579-599.

Njoh, A. (2009). Urban planning as a tool of power and social control in colonial Africa. Planning Perspectives, 24(3), 301-317.

Parnell, S., \& Hart, D. (1999). Self-help housing as a flexible instrument of state control in 20th-century South Africa. Housing Studies, 14(3), 367-386.

Rabinow, P. (1992). France in Morocco: technocosmopolitanism and middling modernism. Assemblage, 17, 52-57.

Reid, A., Lane, P., Segobye, A., Borjeson, L., Mathibidi, N., \& Sekgarametso, P. (1997). Tswana architecture and responses to colonialism. World Archaeology, 28(3), 370-392.

Republic of Botswana. (1968). National Development Plan, 1968-1973. Gaborone: The Government Printer.

Schapera, I. (1935). The social structure of the Tswana ward. Bantu Studies, 9(1), 203-224.

Schapera, I. (1953). The Tswana. London: International African Institute.

Silitshena, R. M. (1979). Chiefly authority and the organization of space in Botswana: Towards an exploration of nucleated settlements among the Tswana. Botswana Notes and Records, 11, 55-67.

Stephens, B., MacLiver, S., \& Weimer-Stutze, I. (1977). Urban Migration in Botswana: Gaborone, December 1975. Botswana Notes and Records, 9, 91-100.

Tlou, T. (1974). The nature of Batswana states: Towards a theory of Batswana traditional government - The Batawana case. Botswana Notes and Records, 6, 57-75.

Truschel, L. W. (1974). Political survival in colonial Botswana: The Preservation of Khama's state and growth of the Ngwato monarchy. Transafrican Journal of History, 4(1/2), 71-93.

Vale, L. (2014). Architecture, power and national identity ( $2{ }^{\text {nd }}$ ed.). New York, NY: Routledge.

Wareus, J. (n.d.). The traditional Tswana village: A neglected planning prototype. Unpublished manuscript.

White, L. (1990). The comforts of home: Prostitution in colonial Nairobi. Chicago, IL: University of Chicago Press.

Wright, G. (2001). The ambiguous modernisms of African cities. In O. Enwezor (Ed.), The short century: Independence and liberation movements in Africa, 1945-1994 (225-233). New York, NY: Prestel.

\section{Archival References}

Atkins, D. A. T. (1960, May 9). Letter to Government Secretary. Gaborone: Botswana National Archives, DCG. 15/13.

Bechuanaland Protectorate. (1956, May 3). Minutes of a meeting with the Government Secretary. Gaborone: BNA, S.73/2/1.

Bechuanaland Protectorate. (1961, December). Minutes of a meeting on housing low income workers. Gaborone: BNA, S.589/9.

Bechuanaland Protectorate. (1962, June). Visit to Johannesburg to investigate African housing. Gaborone: S.589/9.

Bechuanaland Protectorate. (n.d.). Gaberones Township report. Gaborone: BNA, S.73/3/1-2.

Department of Public Works. (1962a, April 5). Low cost housing, paper no. 2. Gaborone: BNA, S.589/9. 
Department of Public Works. (1962b). Gaberones, Bechuanaland Protectorate, Southern Africa, proposed new capital city: A town planning architectural and sociological study of the proposal for the guidance of the Professional Development Team and the Architectural Association School of Tropical Architecture, Bedford Square, London. Gaborone: BNA, BNB 1100, Mafikeng.

Department of Public Works. (1962c). Gaberones capital project: Draft town plan report. Gaborone: BNA, BNB 1098, Mafikeng.

Hansard, P. (1963, March 14). Letter from the Medical Officer of Health. Gaborone: BNA, S.592/11.

Headquarters Development Committee. (1962, April 10). Report of a meeting held in Lobatsi. Gaborone: BNA, S.73/3/1-2.

Headquarters Development Committee. (1962, June 13). Minutes of a meeting. Gaborone: BNA, S.592/9.

Headquarters Development Committee. (1962, December 14). Minutes of a meeting. Gaborone: BNA, S.592/9.

Headquarters Development Sub-Committee. (1962, July 9). Minutes of a meeting. Gaborone: BNA, S.592/10.

Headquarters Development Sub-Committee. (1963, April 17). Minutes of a meeting. Gaborone: BNA, S.592/10.

Legislative Council. (1961). Official report (Hansard 2): Debates of the second meeting of the first session of the first Legislative Council: Sittings from $26^{\text {th }}$ and $27^{\text {th }}$ September, 1961. Gaborone: BNA, 328.6883 NAT.

Legislative Council. (1963). Official report (Hansard 9): Third session, first meeting: Sittings from $18^{\text {th }}$ to $26^{\text {th }}$ November 1963. Gaborone: BNA, BNB 819.

Legislative Council. (1964). Official report (Hansard 12): Fourth session, second meeting: Sittings from $16^{\text {th }}$ to $19^{\text {th }}$ November, 1964. Gaborone: BNA, BNB 822.

Secretary for Townships, Works and Communications. (1963, April 5). Low cost housing at Gaberones. Gaborone: BNA, S.592/11.

Watts, K. (1963, April 9). Letter to the Department of Public Works, Mafikeng. Gaborone: BNA, S.592/11.

Windsor, K. J. (1963, March 26). Note on high density housing. Gaborone: BNA, S.592/11. 